\title{
Tradiční amazonská medicína v české subkultuře
}

\author{
Miroslav Horák ${ }^{1}$ - Šárka Vosáhlová \\ 1 Ústav jazykových a kulturních studií, Fakulta regionálního rozvoje a mezinárodních studií, Mendelova univerzita v Brně
}

Do redakce doručeno 24. března 2016; k publikaci přijato 8. listopadu 2016

\section{TRADITIONAL MEDICINE OF THE AMAZON IN CZECH SUBCULTURE}

\begin{abstract}
This article assesses the present situation in traditional Amazonian medicine in the Czech Republic. It also classifies the types of organized rituals and characterizes their organizers and participants in the country. The fieldwork among traditional Amazonian medicine users was conducted since November 2015. A total of 46 respondents (23 women and 23 men) who had attended at least one ritual of traditional Amazonian medicine were selected for the study and we recorded with them semi-structured interviews. The aim of this article is to categorize their contents. In order to fulfill this objective, we performed a content analysis of interviews based on the Grounded Theory method. In this article we publish results of analysis of the first 15 interviews. These results confirm that in the Czech Republic a psychoactive brew ayahuasca is the most used preparation from traditional Amazonian medicine. Finally, there are risks associated with the use of psychoactive substances indicated.
\end{abstract}

KEY WORDS traditional medicine; Amazon; subculture; Czech Republic; ayahuasca

\begin{abstract}
ABSTRAKT Tento článek obsahuje dosavadní poznatky o tradiční amazonské medicíně v České republice. Rovněž je v něm zahrnuta klasifikace pořádaných obřadů a charakteristika jejich pořadatelů a účastníků. Terénní výzkum mezi uživateli tradiční amazonské medicíny byl realizován od listopadu 2015. Výzkumný vzorek tvoří 46 osob (23 žen a 23 mužů), které se v minulosti s tradiční amazonskou medicínou minimálně jednou zúčastnily nějakého typu rituálu. S těmito osobami byly nahrány semi-strukturované rozhovory. Cílem tohoto článku je kategorizovat jejich obsah. Za tímto účelem jsme provedli obsahovou analýzu interview metodou zakotvené teorie. V tomto článku prezentujeme výsledky analýzy prvních 15 rozhovorů. Tyto výsledky potvrzují, že v České republice je nejčastěji užívaným přípravkem z tradiční amazonské medicíny psychoaktivní odvar ayahuasca. V závěru článku jsou uvedena rizika spojená s užíváním psychoaktivních látek.
\end{abstract}

KLÍČOVÁ SLOVA tradiční medicína; Amazonie; subkultura; Česká republika; ayahuasca

\section{ÚVOD}

Česká subkultura není homogenní. Smolík (2010, 32) píše o subkultuře skinheadů, fotbalových chuligánů, metalistů a jiných jedinců. Souček et al. (2011) se zaměřili na vizuální styl českých subkultur. Tento článek pojednává o subkultuře uživatelů tradiční amazonské medicíny, nebot’ o ní v české odborné literatuře dosud chybí informace.

Subkultura uživatelů tradiční amazonské medicíny má vlastní pohled na sociální realitu a společné specifické problémy. Typické je pro ni užívání psychoaktivních přípravků, které jsou členy této subkultury považovány za lék a svátost. K užívání tradiční amazonské medicíny zde dochází v tzv. autonomních zónách, tedy $\mathrm{v}$ situacích a prostředí, $\mathrm{v}$ nichž se soustředují lidé, kteří zakoušejí svou situaci jako nepřijatelnou či nedostatečnou. Vymykají se tak normám, mechanismům a institucím udržujícím ve společnosti disciplínu a kontrolu (Bey 1991). Abychom do české subkultury uživatelů tradiční amazonské medicíny pronikli, provedli jsme v době od 14. 7. do 31. 8 . 2015 on-line anonymní dotazníkový výzkum, během kterého jsme přes e-mail, Facebook a Google+ oslovili celkem 1452 subjektů, u nichž jsme předpokládali, že by mohly mít s touto medicínou zkušenost. Kromě záměrného, účelového výběru a samosběru byl výběr respondentů realizován metodou sněhové koule (Miovský 2006). V návaznosti na tento výzkum se nám podařilo získat kontakt na 45 dobrovolníků, kteří se byli 
ochotni zúčastnit osobního interview. Na základě rozhovorů $s$ těmito dobrovolníky jsme následně začali mapovat sít lidí, kteři na obřady s tradiční amazonskou medicínou docházejí. Jejich počet nelze přesně stanovit, nicméně dle informátorů tvoří nejméně desetinásobek dobrovolníků zahrnutých do výzkumného vzorku.

Disproporce mezi počtem oslovených jedinců a počtem dobrovolníků zapojených do tohoto výzkumu je dána tím, že některé látky užívané $\mathrm{v}$ rámci tradiční amazonské medicíny jsou na našem území nelegální. Jedná se především o N,Ndimethyltryptamin (zkr. DMT), který je jednou z hlavních obsahových látek ayahuascy, odvaru $\mathrm{z}$ rostlin Banisteriopsis caapi a Psychotria viridis (nebo některé z jejich náhražek, např. Peganum harmala nebo Diplopterys cabrerana). Domníváme se přitom, že ayahuasca je uživateli tradiční amazonské medicíny z výzkumného vzorku užívána nejčastěji. Abychom tuto hypotézu ověřili, provedli jsme terénní výzkum a obsahovou analýzu rozhovorů.

Nutno podotknout, že z výše uvedených právních důvodů je také ayahuasca na našem území užívána subkulturou. Ta se zformovala $v$ šedé zóně na pomezí legality a sdružuje se na základě důvěrných neformálních vazeb a sociálních sítí na internetu.

Ayahuasca - ačkoliv je obvykle považována za klíčový prvek tradiční amazonské medicíny - není jediným rostlinným léčivem původem z Amazonie, který se u nás používá. Své stabilní místo zde mají také různé tonizační, antiparazitární a antiseptické látky dostupné na internetu. Informátoři z našeho výzkumného vzorku kromě ayahuascy také pijí, užívají nosem nebo si do očí kapou tabák. Takováto aplikace byla zdokumentována rovněž u domorodých etnik žijících v tropických deštných lesích Amazonie. Její původní význam je nicméně spíše magicko-religiózní nežli medicínský (Wilbert 1994, 47-76).

Tradiční amazonská medicína představuje systém léčitelských technik, které mohou v zásadě nabýt 3 podob: 1. tradiční a) indiánské (jsou-li prováděny léčiteli původem $z$ některé etnické skupiny žijící v Amazonii, např̀. Aguaruna, Šipibo-Konibo aj.) nebo b) míšenecké (tzn. mestické, pro kterou je typický náboženský synkretismus), 2. neošamanské (kdy sezení vedou nepůvodní organizátoři, např. $\mathrm{z}$ USA nebo $\mathrm{z}$ některé z evropských zemí) a 3. církevní (v tomto případě se jedná o ceremonie původně brazilských synkretických církví, např. Santo Daime, Uñiao do Vegetal nebo některé z jejich odnoží).

\section{SAKRÁLNÍ VS. PROFÁNNÍ ZPŮSOBY UŽÍVÁNÍ AYAHUASCY}

V on-line dotazníkovém šetření jsme zjištovali motivaci participantů na sezeních s ayahuascou. Ukázalo se, že na základě motivace lze uživatele $\mathrm{v}$ zásadě rozdělit do 4 kategorií dle toho, zda se akce účastní 1. z důvodu léčení, 2. ze zvědavosti, 3. ze spirituálních a náboženských pohnutek nebo 4 . kvůli osobnostnímu rozvoji. Minimum respondentů v dotazníku uvedlo, že pije ayahuascu pro rekreaci (Horák 2015, 11).
Během terénního výzkumu jsme se na tuto problematiku zaměřili podrobněji a podařilo se nám získat informace o osobách, které užívají ayahuascu mimo rituální kontext. I tito lidé sice dodržují určitý rituál v tom, jak tento prostředek tradiční amazonské medicíny konzumují, nicméně nedbají na jeho sakrální rovinu.

$\mathrm{Na}$ ayahuascu si není možné vypěstovat fyzickou závislost ve smyslu nárůstu tolerance (tj. potřeby zvyšovat dávku za účelem dosažení týchž účinků) a bažení (angl. craving) po této látce. Neuropsychologické studie nepotvrdily výskyt kognitivních deficitů u jejích dlouhodobých uživatelů (Bouso et al. 2013). Realizované biomedicínské i sociálně-vědné výzkumy naopak potvrzují její využitelnost v léčbě závislosti (Kavenská 2008; Kavenská 2013; Horák 2013; Bogenschütz Johnson 2016; dos Santos et al. 2016).

Jak známo, ayahuasca má silné emetické účinky (vyvolává zvracení a průjem). Od našich informátorů jsme se ale dozvěděli, že existují tací, u nichž jsou po dlouhodobém užívání nevolnost a zvracení eliminovány. Vyloučit tento efekt ale zcela nelze. O bažení dle našeho názoru není možné hovořit, nebot’ ayahuasca má odpornou chut'. Každopádně je ale otázkou, nakolik může mít člověk "potřebu" se sezení s tradiční amazonskou medicínou účastnit.

Potřeba užívat ayahuascu může vycházet nejen $\mathrm{z}$ duchovních, ale také světských důvodů (Eliade 2006). Profánní motivaci osobního (psychického, emocionálního) typu ospravedlňují takové důvody, jako je chronická bolest, rakovina, astma, deprese nebo závislost na alkoholu. Dle studie, kterou provedli Schmid et al. (2010), může díky ayahuasce dojít ke zlepšení copingových strategií vůči nemoci a k nárůstu životní spokojenosti člověka. I další studie dokládají pozitivní efekt ayahuascové zkušenosti na rovině psychické a sociální, který může vést $\mathrm{k}$ opětovnému užívání tohoto nápoje. Mezi změny pozorované účastníky ayahuascových sezení patří: zvýšení sebedůvěry, lepší spojení se sebou samým, zlepšení interpersonálních vztahů, pocit vnitřního klidu a radosti ze života, větší asertivnost a nezávislost (Winkelman 2005; Barbossa et al. 2005; Kjellgren et al. 2009).

Spirituální motivace je na jednu stranu reakcí na neuspokojení duchovních potřeb $\mathrm{v}$ prostředí institucionalizovaných církví. Z tohoto popudu někteří uživatelé ayahuascy inklinují $\mathrm{k}$ obřadům $\mathrm{v}$ tradičním stylu, at už indiánského nebo mestického provedení, nebot takto prožívaná religiozita umožňuje přímý prožitek boží existence. Ti uživatelé, jimž je prostředí institucionalizovaných církví blízké, se přiklánějí k synkretickým církvím, které považují ayahuascu za svátost (Labate 2009).

Jak vyplývá z výše uvedeného, od motivace uživatelů se odvíjí také kontext, v jakém je ayahuasca užívána. Rozdíly v provedení obřadu $\mathrm{v}$ tradičním, neošamanském a církevním stylu jsou diametrální. Před tím, než se jednotlivým variantám budeme věnovat podrobněji, je ale třeba zmínit, že zprofanování ayahuascy k rekreačním a experimentálním účelům může vést $\mathrm{k}$ neblahým následkům.

Rekreační důvody (z lat. recreatio ve významu osvěžení, občerstvení, zotavení) se sice $\mathrm{z}$ etického hlediska mohou jevit 
jako přijatelné, nebot dle informátorů uživání ayahuascy přispívá k obnovení psychické rovnováhy, prohlubuje vztah člověka $\mathrm{k}$ prrírodě a posvátnu. $\mathrm{Na}$ druhou stranu ale zvýšený zájem veřejnosti o účast na obřadech může $\mathrm{v}$ místních podmínkách vést $\mathrm{k}$ rozvoji tzv. ayahuascového turismu (Kavenská - Vosáhlová 2013; Kavenská - Simonová 2014; Kavenská Simonová 2015).

Co se experimentálního užívání ayahuascy týče, $\mathrm{v}$ př́ípadě automedikace bez supervize zkušeným praktikem mohou být následky užití ayahuascy až fatální. Administrace látky je vázána na striktní dietu, která vylučuje z jídelníčku řadu běžných potravin. Porušení restrikcí může vést jak $\mathrm{k}$ umocnění emetických účinků látky, tak ke vzniku nepředvídatelných sekundárních efektů. Lze sice spekulovat o tom, že užívání ayahuascy $\mathrm{v}$ mikrodávkách neceremoniálním způsobem může napomáhat ke zmírnění deprese či některých typů poruchy pozornosti s hyperaktivitou (zkr. ADHD), ovšem takováto aplikace je dosud nepodložená jakýmkoliv seriózním výzkumem a nese s sebou závažná rizika v souvislosti s nepředvídatelnými změnami v lidském chování.

\section{INDIÁNSKÁ A MESTICKÁ FORMA TRADIČNÍ AMAZONSKÉ MEDICÍNY}

K indiánské variantě tradiční amazonské medicíny se ve svém bestselleru pravděpodobně nejvýstižněji vyjadřuje Narby (2006), který ji zkoumal u Ašáninků. Vědecký zájem o tuto problematiku ale zapříčinil Luna (1999). Ten ve svém klasickém díle detailně a názorně představil kosmologii mesticů díky ilustracím malíře a mestického šamana Pabla Amaringa. Ve svém pozdějším díle pak Luna (2002) podrobně vysvětlil principy mestického léčitelství, šp. vegetalismo. Průběh ayahuascového rituálu v tradičním stylu jsme již publikovali dříve, a to jak v indiánském, tak mestickém kontextu (Horák 2013, 56-57; Horák et al. 2015, 9). V České republice patři ke klasickým textům o ayahuasce knihy Kuchaře (2001) a Velíška (2008).

\section{NEOŠAMANISMUS V ČESKÉ REPUBLICE}

Je třeba rozlišovat mezi „tradiční amazonskou medicínou“ (v některých regionech označovanou za šamanismus či léčitelství, šp. curanderismo) a tzv. neošamanismem. Tyto dva směry se sice vzájemně ovlivňují a není je možné jednoznačně oddělit, v některých ohledech se ale zásadně liší (Caiceda 2007).

Šamanismus je považován za archaický náboženský fenomén (Eliade 1997). Vojtíšek (2007) jej definuje jako náboženskou praxi, kterou nacházíme u různých kmenových společenství charakteristických animistickou spiritualitou. O šamanismu lze ale také hovořit „jako o souboru praktik a pojetí týkajících se kosmu, spirituality a lidských potřeb" (DuBois 2011).

Šamanismus má svůj sociální rozměr a je spojován s určitým světonázorem (šp. cosmovisión), jenž předpokládá existenci duše v každé součásti přírody (Horák 2010, 102-103). Naopak neošamanismus je souborem eklektických pověr a praktik, k jejichž oživení došlo v souvislosti se vznikem hnutí New Age (Lužný 1995; Linquist 1997; Bowie 2008; Nešpor 2009).

Mezi tři základní charakteristiky neošamanské praxe, které ji odlišují od tradičního šamanismu, patří: 1. důraz na vědomou volbu (neošamani bývají popisováni jako otevřené a zvídavé osoby, které se k šamanismu dostaly prostřednictvím četby a cestování), 2. individualistická orientace (pomáhání druhým není hlavní cílem praxe neošamanů) a 3. specifická kosmologie (DuBois 2011).

Neošamanismus v České republice nejlépe zpracovaly Petružálková (2013) a Ava (2015).

\section{AYAHUASCA V PROSTŘEDÍ SYNKRETICKÝCH CÍRKVÍ}

V první polovině 20. století došlo v Brazílii k propojení domorodých forem užívání ayahuascy s křestanstvím. Po vzniku synkretických církví se ayahuasca začala používat i mimo tradiční kontext a zvýšil se tak počet a rozmanitost lidí, kteří s ní mají zkušenost (Metzner 2006).

Ke klasickým pracím, jež se vztahují k problematice synkretických církví, patří především text de Alvergy (2007). Feeney a Labate $(2014,111-130)$ se zabývali problematikou globalizace ayahuascových církví z nadnárodní perspektivy. Frenopoulo (2011) analyzoval mechanismy, jimiž se ayahuasca transformovala ve svátost.

K nejznámějším synkretickým církvím, které mají svůj původ $\mathrm{v}$ brazilském Acre a během 20. století se rozšírily do celého světa, patří Santo Daime a Uñiao do Vegetal. Na našem území se v minulosti vyskytovali členové církve Porta do sol.

Členové synkretických církví užívají ayahuascu jako hostii. Watt (2014) zdokumentovala tuto praxi u Santo Daime v Irsku, Blainey (2013) v Belgii a Balzer (2005) v Německu. Kaasik (2016) o ní píše v Estonsku.

\section{ORGANIZÁTOŘI AYAHUASCOVÝCH RITUÁLŮ}

Jména veškerých subjektů zahrnutých do našeho výzkumu byla $\mathrm{z}$ důvodu zachování anonymity změněna.

Ayahuasca je dle našich dosavadních poznatků na území ČR užívána od roku 1999, kdy pravděpodobně v Jihomoravském kraji poprvé realizoval rituály peruánský léčitel, mestic José Alvarez, který je mezi uživateli proslulý tím, že vyléčil jednoho svého pacienta z epilepsie. José Alvarez dodnes př́ležitostně navštěvuje Českou republiku a někteří jeho zdejší pacienti ho rovněž navštěvují v jeho nově zbudovaném léčitelském centru v severoperuánském Iquitos.

Několik informátorů se v roce 2006 zúčastnilo obřadu jiného peruánského léčitele mestického původu, Daniela Quispeho, který spolu se svou přítelkyní pořádal sezení v Jihočeském kraji. Daniel dělal obřady jak individuálního, tak skupinového provedení. Při práci nezpíval, ale pískal léčivé písně, tzv. 
íkara. Dle našich informací zde už dotyčný nadále svou praxi neprovozuje, nebot se vrátil do Peru.

Z formálního hlediska byla sezení pořádaná Danielem velmi podobná práci ekvádorského léčitele, Luise Zambrana, s nímž se nám rovněž podařilo navázat kontakt. Oba dělali obřady celonoční, po nichž následovalo sdílení zážitků s léčitelem spojené s interpretací vizí. Jediným rozdílem bylo, že Daniel neprováděl tzv. individuální očistu, při které léčitel pracuje s každým účastníkem rituálu zvlášt a používá různé tradiční léčebné metody jako okuřování tabákem, kladení rukou nebo sání energetických drah a center. Daniel používal pouze parfémy (tj. obyčejně Agua florida).

Luis Zambrano organizuje své obřady od roku 2012 ve Východočeském kraji. Dle našich informátorů má v Čechách svého žáka, Jiřího Horáka, který sice používá obdobné metody, nicméně vzájemně se oba rozcházejí v odlišné etice práce. Zatímco klienti ekvádorského léčitele platí za účast na obřadu předepsaný finanční obnos, český léčitel provádí svou práci za dar, který mu pacient složí dle vlastního uvážení. Z utilitárního hlediska tato praxe slouží primárně ke zvýšení jeho prestiže. Jiř́ vede samostatnou praxi od loňského roku.

Dále jsme hovořili s klienty Milana Buriana, Čecha, který pořádá rituály $\mathrm{v}$ pražských tanečních sálech. $\mathrm{V}$ tomto př́padě naši informátoři uváděli, že setkání trvalo ve srovnání s jinými pořadateli výrazně kratší dobu (tj. orientačně do půlnoci), a potom se - pravděpodobně ještě pod vlivem ayahuascy - účastníci rozcházeli do svých domovi̊. Tuto praktiku považujeme za značně rizikovou s ohledem na vznik možných incidentů, $\mathrm{k}$ nimž může bez supervize ve změněném stavu vědomí dojít. Kromě toho může mít takovéto chování negativní vliv na integraci zkušenosti jako takové. Milan Burian se každopádně na rozdíl od ostatních organizátorů nedopouští ilegální činnosti, nebot při prrípravě svého přípravku používá výhradně liánu Banisteriopsis caapi. Beta-karbolinové alkaloidy nejsou na území ČR ilegální.

Dalším pořadatelem, kterého jsme navštívili za účelem realizace interview, byl holandský neošaman, Arnold Uhlenbeck, který zakládá svou praxi na procesové práci nebo také procesově orientované psychologii (POP) a zkušenostech, které získal v Santo Daime. Arnold pořádá prŕíležitostně obřady v soukromém penzionu v Královéhradeckém kraji.

Poslední významnou skupinu našich informátorů reprezentují účastníci na akcích, které v Moravskoslezském kraji vede bývalý člen brazilské synkretické církve Porta do sol, Jiří Novák (MacRae 2004).

\section{ÚČASTNÍCI OBŘADŮ S AYAHUASCOU}

Obecně vzato uživatelé ayahuascy inklinují k psytrancové hudební scéně, alternativní medicíně, astrologii a východní náboženské filozofii. Valná většina našich informátorů má předešlé zkušenosti s psychoaktivními látkami (nap̌r. s marihuanou, psilocybinem nebo diethylamidem kyseliny lysergové). Nejedná se ale o osoby, které by tyto substance měly tendenci užívat k zábavním účelům. Naopak, považujeme je za tzv. zodpovědné uživatele, kteří dbají na odpovídající set a setting a preferují př́rodě blízké typy zážitků, kdy dochází k užívání psychoaktivních látek spíše ve venkovském prostředí nežli v prostředí industriálního velkoměsta.

Mezi našimi informátory navíc nejenže nejsou jedinci, kteří by měli ve zvyku psychoaktivní látky zneužívat, ale ani lidé, kteří by je brali osamoceně. Stejně tak př́pravky tradiční amazonské medicíny, at už se jedná o ayahuascu nebo tabák, užívají vždy pod dohledem. Obřadů se obvykle účastní průměrně 15 osob.

\section{PŘÍPRAVA NA OBŘAD}

Účast na obřadu je možná pouze na doporučení někoho, kdo je již členem subkultury. Veškerá komunikace probíhá převážně osobně nebo e-mailem. Nový zájemce po př̀hlášení obdrží instrukce dané pořadatelem, které kromě informací o místě konání akce obsahují také seznam potravin, které musí $\mathrm{v}$ rámci tzv. IMAO diety vynechat před a po sezení z jídelníčku. Minimální doba pro držení diety je 3 dny, každopádně doporučuje se držet ji déle (tzn. alespoň 5 dní předem). Lépe než uvádět podrobný výčet všech pokrmů, na něž se váže restrikce, řekněme, že se doporučuje konzumovat pouze vařená rýže bez soli, pohanková (špaldová nebo ovesná) kaše, vejce, voda a bylinkové čaje. Účasti na ayahuascovém obřadu by se měly vyvarovat osoby užívající antidepresiva $z$ kategorie inhibitorů zpětného vychytávání serotoninu, zkr. SSRI (Katzung et al. 2015) a těhotné ženy. Vyloučena je konzumace alkoholu a jiných psychoaktivních látek (Fantegrossi et al. 2008).

Poplatek za účast na obřadu $\mathrm{v}$ př́ípadě většiny organizátorů, k nimž naši informátoři docházejí, činí průměrně 2 tis. Kč (včetně ubytování). Pouze jeden z pořadatelů, jak jsme již zmínili výše, nemá cenu předem stanovenu.

\section{KOMERČNÍ A LEGÁLNÍ ASPEKTY UŽÍVÁNÍ AYAHUASCY}

Mimo vědecký diskurz vykazuje užívání ayahuascy řadu právních rozporů. Mezinárodní rada pro kontrolu narkotik (International Narcotics Control Board, zkr. INCB) při OSN ji nereguluje. Každopádně ale penalizuje konzumaci DMT, substance, již ayahuasca obsahuje, pokud tedy není podávána jako tzv. purgahuasca bez této prríměsi. V České republice je DMT ilegální dle nařízení vlády č. 463/2013 Sb., O seznamech návykových látek.

Francie je jedinou zemí, kde je DMT zakázáno nikoliv kvůli svým efektům, nýbrž kvůli spojitosti s činností La Maison qui chante, l'Institut français de recherche et d'expérimentation sur les thérapies traditionnelles (IFRETT) se sídlem v Nantes. Toto centrum, které ve Francii reprezentuje peruánské Centrum pro rehabilitaci toxikomanů a výzkum tradiční medicíny, Takiwasi, bylo Národním svazem asociací na obranu rodiny a jednotlice (l'Union nationale des associations de défense des families et du l'individu, zkr. UNADFI) prohlášeno za sektu. 


\begin{tabular}{|c|c|c|c|c|c|l|}
\hline ID & Pohlaví & Rodinný stav & Věk & Národnost & Vzdělání & \multicolumn{1}{|c|}{ Zaměstnání } \\
\hline G01 & muž & ženatý & 36 & česká & VŠ & starosta obce \\
\hline G02 & žena & svobodná & 26 & česká & VŠ & malírka \\
\hline G03 & žena & svobodná & 24 & česká & VŠ & psycholožka \\
\hline G04 & žena & svobodná & 22 & česká & SŠ & studentka \\
\hline G05 & muž & ženatý & 35 & česká & VŠ & akademický pracovník \\
\hline G06 & muž & svobodný & 27 & česká & VŠ & architekt \\
\hline G07 & žena & svobodná & 38 & česká & SŠ & administrátorka klinických studií \\
\hline G08 & muž & ženatý & 35 & česká & VŠ & geodet, zeměměřč \\
\hline G09 & žena & vdaná & 34 & česká & SŠ & t. č. na mateřské dovolené \\
\hline G10 & žena & svobodná & 35 & česká & SŠ & propagace a reklama \\
\hline G11 & muž & ženatý & 32 & česká & VŠ & obchodník, podnikatel \\
\hline G12 & žena & vdaná & 25 & česká & SŠ & t. č. na mateřské dovolené \\
\hline G13 & žena & svobodná & 38 & česká & VŠ & architektka \\
\hline G14 & muž & svobodný & 44 & česká & VŠ & restaurátor \\
\hline G15 & žena & svobodná & 28 & česká & VŠ & postgraduální studentka \\
\hline
\end{tabular}

Tab. 1. Charakteristika výzkumného vzorku (zdroj: vlastní zpracování).

V zemích jako je Brazílie, Nové Mexiko a Holandsko, je díky synkretickým církvím pořádání ayahuascových obřadů uznáno za náboženský akt. V ostatních zemích (včetně ČR) není takováto činnost $\mathrm{v}$ religiózním (ani jiném kontextu) legální. Hovoříme proto o tzv. skrytých (undergroundových nebo tajných) církvích, nebot z důvodu pronásledování nemohou být jejich obřady vykonávány veřejně. Tajná činnost je pak navenek prezentována jako nenáboženská soukromá aktivita (Kautzer 2012).

Dle informací poskytnutých Nadací na ochranu ayahuascy (Ayahuasca Defense Fund, zkr. ADF), která funguje při Mezinárodním centru pro vzdělávání, výzkum a služby v etnobotanice (International Centre for Ethnobotanical Education, Research and Services, zkr. ICEERS), lze od roku 1999 po celém světě sledovat strmý nárůst $\mathrm{v}$ počtech zatčení, $\mathrm{k}$ nimž došlo budto na základě odhalení nádob s tímto přípravkem při jejich převozu přes hranice, příp. policie odhalila poštovní zásilku s ingrediencemi a následně zadržela pachatele při jejím převzetí (ADF 2016). Takovýto prŕípad byl například zdokumentován v Litvě (Ellens - Roberts 2015).

Nutno podotknout, že $\mathrm{v}$ tomto př́ípadě je třeba rozlišovat mezi „narkotrafikanty“ a „mikrotrafikanty“. Prvním termínem označujeme osoby, které se zabývají průmyslovou výrobou a distribucí ilegálních psychoaktivních látek. Druhý zahrnuje osoby, které se opakovaně dopouštějí trestného činu nedovoleného obchodu s omamnými a psychotropními látkami v malém množství. $\mathrm{V}$ tomto př́padě se jedná o delikt nedovoleného podnikání. Takovéto zločiny jsou charakteristické tím, že mají společného pachatele, který jedná sám za sebe a nezávisle na ostatních (Ávila Martinéz 2011).

Cílem této studie nicméně není klasifikovat organizátory sezení s tradiční amazonskou medicínou z právního hlediska, ani je stigmatizovat jako osoby, které se dopouštějí trestných činů. At už je ale budeme chtít nahlížet ve své autenticitě z jakékoliv perspektivy, ekonomické a politické aspekty této problematiky nemůžeme zcela pominout.

\section{METODOLOGIE}

Od 1. 11. 2015 do 27. 9. 2016 jsme realizovali terénní výzkum, prováděli zúčastněné pozorování na obřadech a nahrávali semi-strukturované rozhovory s uživateli tradiční amazonské medicíny. Jak bylo uvedeno výše, rozhovory byly realizovány s dobrovolníky, kteři se přihlásili na základě předešlého dotazníkového šetření, resp. se je podařilo kontaktovat přes informátory.

Během zmiňovaného období se nám podařilo pořídit celkem 46 semi-strukturovaných rozhovorů o průměrné délce 50 min. (směrodatná odchylka: 20:50). Celkový čas audiozáznamu činí 2358:22 min. (tj. 39:30 hod.).

Výzkumný vzorek tvoří celkem 23 žen a 23 mužů, kteří se $\mathrm{v}$ minulosti minimálně jednou zúčastnili nějakého typu obřadu s tradiční amazonskou medicínou. Průměrný věk informátora činil 34,5 roků (směrodatná odchylka: 11,8). Nejmladší informátor měl 22 let, nejstarší 70. Co se rodinného stavu týče, 58,6\% informátorů bylo svobodných, 23,9\% ženatých a $17,4 \%$ rozvedených. $54,3 \%$ informátorů mělo ukončené vysokoškolské vzdělání, 41,3\% středoškolské a 4,4\% vystudovalo vyšší odbornou školu. 91,3\% osob bylo české národnosti. Kromě toho se ve výzkumném vzorku objevili občané polské, nizozemské a slovenské národnosti. Jejich počet ale není statisticky významný.

Co se povolání týče, mezi informátory se vyskytli starostové, 


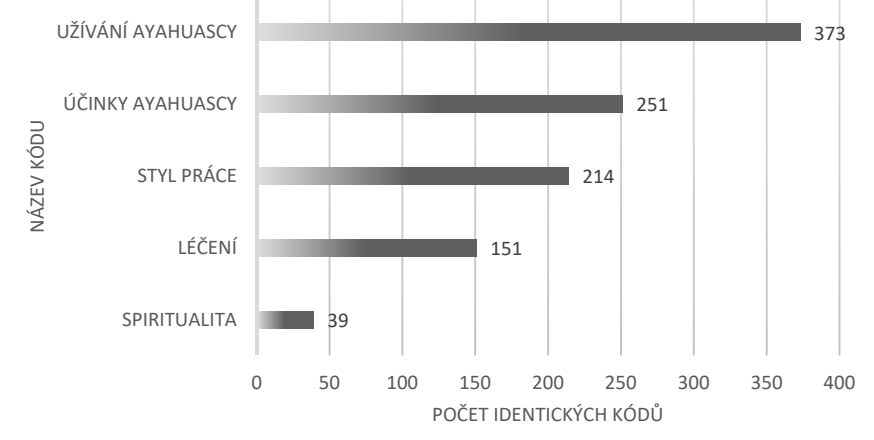

Graf 1. Přehled kódů nejvíce zakotvených ve výpovědích informátorů (zdroj: vlastní zpracování)

malíři, psychologové, studenti, architekti, administrátoři, ženy na mateřské dovolené, akademičtí pracovníci, terapeuti, neurologové, vojáci z povolání, IT specialisté, grafici, ekonomové, hudebníci, zemědělci, psychoterapeuti, novináři, překladatelé, lékaři, technici i důchodci. Nikdo nebyl nezaměstnaný. Vzhledem k množství sesbíraných dat v tomto článku prezentujeme pouze dílčí analýzu 15 interview, které jsme pořídili nejdřive. $\mathrm{V}$ tabulce 1 uvádíme charakteristiku vybraných informátorů včetně údajů o jejich rodinném stavu a profesi.

Rozhovory s informátory jsme analyzovali metodou zakotvené teorie (Strauss, Corbin 2002). Každý audiozáznam byl přepsán a kódován v Tabulkách Google. Pro zajištění reliability a validity dat jsme prováděli jejich triangulaci. Triangulace byla založena na tom, že do sběru a analýzy dat bylo zapojeno celkem 5 výzkumníků, kteří reprezentují odlišné vědní disciplíny, tj. antropologii, psychologii, religionistiku a mezinárodní vztahy. Ke sběru dat navíc docházelo v různý čas, na různých místech a od různých osob.

U všech přepisů jsme nejprve provedli otevřené kódování, které spočívalo $\mathrm{v}$ tom, že jsme $\mathrm{k}$ dílčím jednotkám analýzy (definovaným délkou jednoho odstavce) přiřadili určitý kód. Hotové kódy z otevřeného kódování jsme vykopírovali do zvláštního listu a ke každému jsme do vedlejšího sloupce doplnili souřadnice výpovědi, ke které odkazuje. Souřadnice, složená z identifikátoru informanta a os výchozí buňky, slouží ke zpětnému dohledání výpovědi.

Množství identických kódů vyjadřuje to, jak moc je daný jev zakotvený (angl. grounded) ve výpovědích informátorů. Hotové kódy lze také shlukovat tematicky do tzv. rodin kódů dle nadřazeného kódu. Rodiny kódů, které se vyznačují sémantickou př́buzností, lze následně zobrazit graficky. Počet kódů navázaných na nadřazený kód vyjadřuje jeho hustotu (angl. density), tzn. jak moc je propojený s ostatními.

Ve druhém kroku jsme dělali axiální kódování, kdy jsme implicitně vybírali z nabídky vytvořené Straussem a Corbinovou (2002) a kategorizovali kódy podle toho, zda se jednalo o příčinné podmínky, intervenující podmínky, jevy, kontext, jednání/interakce nebo následky (šp. matriz condicional/consequencial, condiciones/consequencias macro o micro, sendas de conectividad, contingecias).

Jakmile jsme měli otevřené a axiální kódování u všech tran- skriptů hotovo, přistoupili jsme ke kódování selektivnímu. Výsledky otevřeného kódování jsme v tomto kroku roztřídili dle axiálních kódů a hledali jsme mezi nimi kauzální vztahy. $\mathrm{Na}$ základě tohoto postupu jsme výsledky na závěr interpretovali.

\section{VÝSLEDKY}

Během otevřeného kódování výpovědí informátorů jsme vytvořili 1147 kódů. V grafu 1 uvádíme přehled kódů, které jsou ve výpovědích nejvíce zakotveny.

Z grafu 1 je zjevné, že užívání ayahuascy představuje ve výpovědích našich informátorů stěžejní téma. Ayahuasca má mezi rostlinnými př́pravky $\mathrm{z}$ tradiční amazonské medicíny dominantní roli. Aplikace ostatních léčivých látek z Amazonie je mezi uživateli zastoupenými $\mathrm{v}$ našem výzkumném vzorku zanedbatelná.

Zaměříme-li se na účinky ayahuascy, setkáme se ve výpovědích informátorů se zajímavými tvrzeními, např. že ayahuasca účinkuje nezávisle na kulturním pozadí, ukazuje člověku lepší stránku jeho osobnosti a problémy, kterými trpí, nebo že vyvolává změnu v sebepojetí. Za zajímavé lze také považovat, že podle informátorů zlepšuje vnímání vlastního těla a prožívání, zesiluje empatii a aktivuje samoléčebné procesy. Informátoři také potvrzují, že vyvolává typické fyziologické reakce, jako jsou zvracení a křeče.

Co se stylu práce týče, léčitelé $\mathrm{v}$ České republice používají nezávisle na svém původu techniky, které jsou v Amazonii obvyklé (např. sání, okuřování tabákem, ometání metličkou shacapa/surupanga, kladení rukou anebo aplikace parfémů). Specificky českou technikou je čistění pálenkou, která se místy používá také k vyplachování úst.

K pomůckám léčitelů patří různá chřestidla a hudební nástroje. Místy se používají také zpěvníky. Ve většině případů ale zpívají organizátoři spolu s účastníky íkara (a to nejen ve španělštině a různých indiánských jazycích, ale také $\mathrm{v}$ češtině nebo ruštině). Na konci sezení se většinou sdílejí zážitky, což pacientům pomáhá integrovat jejich zážitky změněných stavů vědomí do každodenního života.

Ohledně léčení informátoři uvádějí, že „léčení je práce“, čímž chtějí vyjádřit úsilí, které je nutné vynaložit pro překonání nevábné chuti ayahuascy a nepř́ijemných somatických efektů. Obřadů se lze v České republice zúčastnit celoročně, každopádně uživatelé preferují letní měsíce. Současně platí, že na rituály nejezdí vždy sami. U sezdaných uživatelů je obvyklé, že ayahuascu a další rostliny užívají i ostatní členové jejich rodiny. Spiritualitu informátorů lze charakterizovat jako nenáboženskou, nebot' v jejich výpovědích se převážně setkáme s odporem $\mathrm{k}$ institucionalizovaným církvím a nedůvěrou $\mathrm{v}$ dogmata. Informátoři obvykle věří v sebe sama anebo v prrírodu. Domnívají se, že je možné na emocionální úrovni komunikovat $\mathrm{s}$ rostlinami, věří $\mathrm{v}$ nadpřirozenou energii a mnohovrstevnatost lidského života. Někteř́i z nich kromě animismu a panteismu inklinují také ke katolicismu, zen buddhismu anebo judaismu. 


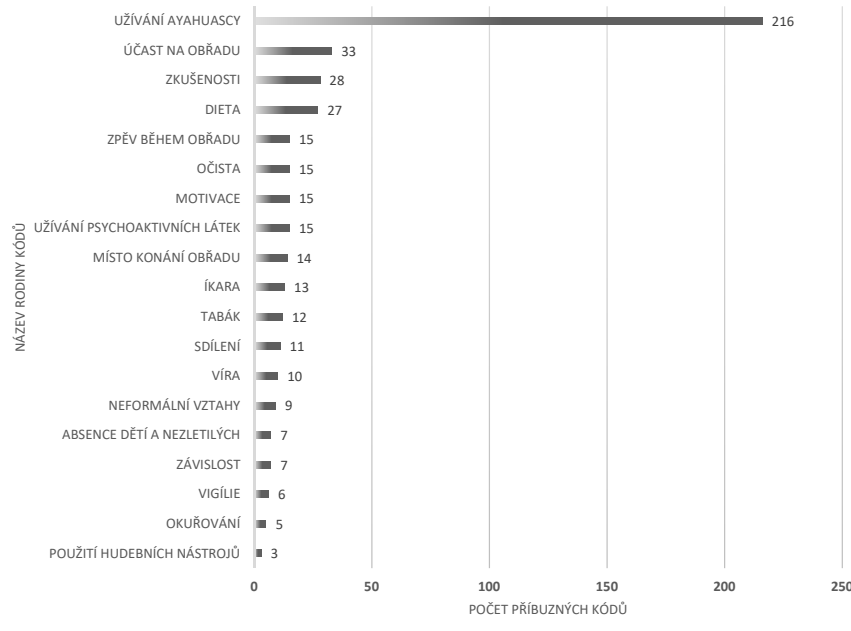

Graf 2. Přehled kódů s největší hustotou (zdroj: vlastní zpracování)

Graf 2 zobrazuje rodiny kódů, kterých jsme identifikovali celkem 19. Mezi těmito kódy opět jednoznačně vyniká užívání ayahuascy.

Podle informátorů ayahuasca pomáhá člověku k tomu, aby se zaměřil sám na sebe, $\mathrm{k}$ fyzické očistě a psychickému odpočinku, k lepší organizaci života a rozvinutí talentu, k sebepoznání, nalezení smyslu života. Je vhodná při dýchacích potížích, ekzémech, střevních potížích a léčbě závislosti a $\mathrm{v}$ př́padě neurotických poruch. Umožňuje člověku zbavit se strachu a vnitřní agrese.

\section{ZÁVĚR}

Tento článek shrnuje aktuální poznatky o tradiční amazonské medicíně v České republice. Výsledky našeho výzkumu potvrdily, že nejčastěji užívaným př́ipravkem $\mathrm{z}$ tradiční amazonské medicíny je v místních podmínkách psychoaktivní odvar ayahuasca. Kromě teoretických pasáží obsahuje tento článek také data o účastnících a organizátorech sezení, preskripcích při užívání ayahuascy a typech obřadů pořádaných na našem území.

Doposud se nám podařilo shromáždit data o 46 osobách, které se min. jednou zúčastnily obřadu u některého $\mathrm{z} 6$ pořadatelů. Tyto pořadatele jsme $\mathrm{z}$ koncepčních důvodů rozdělili do 3 základních kategorií na: 1. tradiční indiánské a mestické léčitele, 2 . neošamany a 3 . členy synkretických církví.

Tato typologie odráží nejen odlišný styl práce jednotlivých organizátorů, který je založen na odlišných sociokulturních východiskách každého z nich (jež se vyznačují společnými rysy), ale také reflektuje motivaci účastníků a jejich individuální potřeby.

Motivace účastníků pro účast na ayahuascovém obřadu osciluje od zvědavosti a touhy po sebepoznání a osobnostním rozvoji, přes léčení různých psychosomatických onemocnění až k realizaci spirituálních a náboženských potřeb. Uspoko- jení těchto potřeb mohou jednotlivé kontexty, $\mathrm{v}$ nichž pořadatelé své obřady organizují, nabídnout. Výpovědi našich informátorů potvrzují, že se u nás ayahuasca užívá převážně v (neklinickém) terapeutickém nebo sakrálním rámci.

Jak bylo naznačeno výše, užívání ayahuascy s sebou nese určitá sociální a zdravotní rizika. Ta jsou o to významnější, má-li člověk tendenci nakládat s psychoaktivními látkami typu ayahuasca individuálně. Objednat si hotovou ayahuascu přes internet, př́p. ji vařit na vlastní pěst může vést $k$ nepředvídatelným následkům. Takovéto jednání navíc může přitáhnout pozornost správních orgánů.

Obzvlášt ty osoby, které uvažují o tom, že by obřad s ayahuascou podstoupily, by měly věnovat pozornost kontradikcím, které jsme naznačili výše. Jedinci trpící psychotickými poruchami by se měli podobným zkušenostem vyhnout zcela, nebo minimálně své záměry předem konzultovat s odborným zdravotnickým personálem.

Před tím, než se budeme věnovat terapeutickému využití ayahuascy v klinických podmínkách, resp. legálně v náboženském kontextu, je třeba dobře zvážit limity a rizika, které s sebou její užívání a podávání nese (Tupper 2008; Trichter 2010).

\section{PODĚKOVÁNÍ}

Autoři tohoto článku velice děkují Mgr. et Mgr. Romaně Lukášové, Bc. Wandě Vozáryové a Kamile Wrožynové za pomoc při sběru dat v rámci terénního výzkumu. Díky patří také Nurii Romo Avilés za inspiraci při psaní pasáže o komerčních a legálních aspekech užívání ayahuascy. Tato publikace vznikla jako výstup projektu Glokalizace tradiční amazonské medicíny $v$ České republice a možnosti jejího terapeutického využití (identifikační č.: 2016/003), který by nebylo možné realizovat bez finanční podpory Interní grantové agentury Fakulty regionálního rozvoje a mezinárodních studií Mendelovy univerzity v Brně.

\section{LITERATURA}

ADF (2016): International legal status. Retrieved from: http://goo.gl/YQfUsT Ava, V. (2015): Ayahuaskové rituály praktikované v Praze a význam, jaký jim prikládají jejich aktérí. Praha: Univerzita Karlova v Praze, Fakulta humanitních studií. Bakalářská práce.

Ávila Martinéz, A. F. (2011): Colombia: Criminalidad urbana y narcomenudeo. MafiaAndCo, 12, 48-61.

Balzer, C. (2005): Ayahuasca Rituals in Germany: The First Steps of the Brazilian Santo Daime Religion in Europe. Curare, 28(1), 57-70.

Barbosa, P. C. R. - Giglio, J. S. - Dalgalarrondo, P. (2005): Altered States of Consciousness and Short-Term Psychological After-Effects Induced by the First Time Ritual Use of Ayahuasca in an Urban Context in Brazil. Journal of Psychoactive Drugs, 37(2), 193-201.

Bey, H. (1991): T. A. Z. The temporary Autonomous Zone, ontological anarchy, poetic terrorism. New York: Automedia/Anti-Copyright.

Blainey, M. G. (2013): A Ritual Key to Mystical Solutions: Ayahuasca Therapy, Secularism, \& the Santo Daime Religion in Belgium. New Orleans: Tulane University, School of Liberal Arts, Department of Anthropology.

Bogenschutz, M. P. - Johnson, M. W. (2016): Classic Hallucinogens in the Treatment of Addictions. Progress in Neuro-Psychopharmacology and Biological Psychiatry, 64, 250-258. 
Bouso, J. C. - Fábregas, J. M. - Antonijoan, R. M. - Rodríguez-Fornells, A. - Riba, J. (2013): Acute Effects of Ayahuasca on Neuropsychological Performance: Differences in Executive Function between Experienced and Occasional Users. Psychopharmacology, 230(3), 415-424.

Bowie, F. (2008): Antropologie náboženství. Praha: Portál.

Caiceda, A. (2007): Neochamanismos y modernidad. Lecturas sobre la emancipación. Nómadas, 26, 114-127.

de Alverga, A. P. (2007): Prales vizí. Ayahuasca, amazonská spiritualita a tradice Santo Daime. Praha: Triton.

de Rios, M. D. - Grob, C. S. - Doering-Silveira, E. - Lopez, E. - Da Silviera, D. X. - Alonso, L. K. - Doering-Silveira, E. (2005): Ayahuasca in Adolescence: Qualitative Results. Journal of Psychoactive Drugs, 37(2), 135-139.

Doering-Silveira, E. - Lopez, E. - Grob, C. S. - de Rios, M. D. - Alonso, L. K. - Tacla, C. - Shirakawa, I. - Bertolucci, P. H. - Da Silviera, D. X. (2005): Ayahuasca in Adolescence: A Neuropsychological Assessment. Journal of Psychoactive Drugs, 37(2), 123-128.

dos Santos, R. - Osório, F. L. - Crippa, J. A. S. - Riba, J. - Zuardi, A. W. - Hallak, E. C. (2016): Antidepressive, Anxiolytic, and Antiaddictive Effects of Ayahuasca, Psilocybin and Lysergic Acid Diethylamide (LSD): A Systematic Review of Clinical Trials Published in the Last 25 Years: Antidepressive Effects of Ayahuasca, Psilocybin and LSD. Therapeutic Advances in Psychopharmacology, 6(1) 1-21.

DuBois, T. A. (2011): Úvod do šamanismu. Praha: Volvox Globator.

Eliade, M. (1997): Šamanismus a nejstarši techniky extáze. Praha: Argo.

Eliade, M. (2006): Posvátné a profánní. Praha: Oikoymenh.

Ellens, J. H. - Roberts, T. B. (2015): The Psychedelic Policy Quagmire: Health, Law, Fre-edom, and Society. Santa Barbara: ABC-CLIO.

Feeney, K. - Labate, B. C. (2014): The Expansion of Brazilian Ayahuasca Religions: Law, Culture and Locality, In: Cavnar, C. - Labate, B. C. (eds.) Prohibition, Religious Freedom and Human Rights: Regulating Traditional Drug Use. Berlin Heidelberg: Springer-Verlag.

Fantegrossi, W. E. - Murnane, K. S. - Reissig, C. J. (2008): The Behavioral Pharmacology of Hallucinogens. Biochemical Pharmacology, 75(1), 1733.

Frenopoulo, C. (2011): Uso introspectivo de la ayahuasca: surgimiento de las iglesias. Trama, 3, 42-54.

Goméz García, P. (1996): Teorías étnicas y etnológicas sobre la terapéutica popular, In: González Alcantud, J. A. - Rodríguezz Becerra, S. (eds.) Creer y curar: La medicina popular. Granada: Diputación Provincial de Granada, 209-250.

Horák, M. (2010): Př́ípad Takiwasi - Koncept tradiční domorodé medicíny peruánské Amazonie. AntropoWebzin, 6(2), 101-107.

Horák, M. (2013): Di̊m, kde se zpívá: rehabilitace drogově závislých tradiční domorodou medicínou peruánské Amazonie. Brno: Mendelova univerzita $\mathrm{v}$ Brně.

Kaasik, H. (2016): Psychology of Ayahuasca Users in Estonia. Tartu: University of Tartu, Institute of Psychology. Magisterská práce.

Katzung, B. G. - Masters, S. B. - Trevor, A. J. (2015): Lange's Basic and Clinical Pharmacology. New York, NY: McGraw-Hill Professional.

Kautzer, K. (2012): The Underground Church. Nonviolent Resistance to the Vatican Empire. Leiden: Brill.

Kavenská, V. (2008): Možnosti využití halucinogenu ayahuasky při léčbě závislostí. Adiktologie, 8(1), 32-40.

Kavenská, V. (2013): Tradiční medicína Jižní Ameriky a její využití v psychoterapii. Olomouc: Univerzita Palackého v Olomouci.

Kavenská, V. - Vosáhlová, Š. (2013): Zkušenosti s ayahuaskou v Evropě - motivace, možné prŕnosy a rizika. E-psychologie, 7(4), 28-39.

Kavenská, V. - Simonová, H. (2014): Zkušenost s halucinogenní rostlinou ayahuasca v kontextu šamanského rituálu. Anthropologia integra, 5(1), 51-63.

Kavenská, V. - Simonová, S. (2015): Ayahuasca Tourism: Participants in Shamanic Rituals and their Personality Styles, Motivation, Benefits and Risks. Journal of Psychoactive Drugs, 47(5), 351-359.

Kjellgren, A. - Eriksson, A. - Norlander, T. (2009): Experiences of Encounters with Ayahuasca - „the Vine of the Soul“. Journal of Psychoactive Drugs, 41(4), 309-315.

Kuchař, J. (2001): Ayahuasca aneb Tanec s Bohy. Praha: Eminent.

Labate, B. C. - Santana de Rose, I. - Guimarães dos Santos, R. (eds.) (2009): Ayahuasca Religions: A Comprehensive Bibliography and Critical Essays. Santa Cruz, CA: MAPS.
Labate, B. C. (2011): Consumption of Ayahuasca by Children and Pregnant Women: Medical Controversies and Religious Perspectives. Journal of Psychoactive Drugs, 43(1), 27-35.

Linquist, G. (1997): Shamanic Performances on the Urban Scene: Neo-shamanism in Contemporary Sweden. Stockholm: Stockholm University, Department of Social Anthropology.

Luna, L. E. (1999): Ayahuasca Visions. The Religious Iconography of a Peruvian Shaman. Berkeley, CA: North Atlantic Books.

Luna, L. E. (2002): Vegetalismo. Šamanismus mezi mestickým obyvatelstvem peruánské Amazonie. Praha: DharmaGaia.

Lužný, D. (1995): Neošamanismus - postmoderní techniky extáze: k problematice náboženství v dnešní době. Religio: revue pro religionistiku, 3(2), $169-180$.

Metzner, R. (2006): Sacred Vine of Spirits: Ayahuasca. Rochester: Park Street Press.

Miovský, M. (2006): Kvalitativní prístup a metody v psychologickém výzkumu. Praha: Grada Publishing.

MacRae, E. (2004): The Ritual Use of Ayahuasca by Three Brazilian Religions, In: Coomber, R. - South, N. (eds.) Drug Use and Cultural Contexts Beyond the West. London: Free Association Books, 27-45.

Narby, J. (2006): Kosmický had. Praha: Rybka Publishers.

Nešpor, Z. R. (2009): Spirituální podnikání v České republice: soukromý a korporativní sektor. Lidé města / Urban People, 11(1), 163-191.

Petružálková, K. (2013): Ayahuascová subkultura v Praze. Praha: Univerzita Karlova v Praze, Filozofická fakulta. Diplomová práce.

Schmid, J. T. - Jungaberle, H. - Verres, R. (2010): Subjective Theories about (Self-) Treatment with Ayahuasca. Anthropology of Consciousness, 21(2), $188-204$.

Smolík, J. (2010): Subkultury mládeže. Uvedení do problematiky. Praha: Grada Publishing.

Souček, T. - Veselý, K. - Vladimír 518 (2011): Kmeny. Současné městské subkultury. Praha: BiggBoss, Yinachi.

Strauss, A. - Corbinová, J. (1999): Základy kvalitativního výzkumu. Postupy a techniky zakotvené teorie. Brno: Sdružení Podané ruce, Boskovice: Nakladatelství Albert.

Trichter, S. (2010): Ayahuasca beyond the Amazon. The Benefits and Risks of a Spreading Tradition. The Journal of Transpersonal Psychology, 42(2), 131-148.

Tupper, K. W. (2008): The Globalization of Ayahuasca: Harm reduction or Benefit Maximization? International Journal of Drug Policy, 19(4), 297-303.

Velíšek, I. (2008): Cesta s ayahuaskou. Praha: Volvox Globator.

Vojtíšek, Z. (2007): Nová náboženská hnutí a jak jim porozumět. Praha: Beta Books.

Watt, G. (2014): Santo Daime in Ireland: A 'Work' in Process. Diskus, 16(3), 47-56.

Wilbert, J. (1994): The Cultural Significance of Tobacco Use in South America, In: Seaman, D. - Jay, G. S. (eds.) Ancient Traditions: Shamanism in Central Asia and the Americas. Denver, CO: University Press of Colorado \& Denver Museum of Natural History.

Winkelman, M. (2005): Drug tourism or spiritual healing? Ayahuasca seekers in Amazonia. Journal of Psychoactive Drugs, 37(2), 20-218.

Zamudio Angles, C. A. (2008): ¿Qué es el narcomenudeo? Un acercamiento etnológico. Liberaddictus, 103, 3-7.

Zamudio Angles, C. A. (2013): Jóvenes en el narcomenudeo: el caso Ciudad de México, URVIO, Revista Latinoamericana de Seguridad Ciudadana, $13,111-123$

\section{AUTOŘI}

Miroslav Horák (1981, Zlín), sociální a kulturní antropolog, ekolog a pedagog. Specializuje se na etnobotaniku a fytoterapii. Na Ústavu jazykových a kulturních studií Fakulty regionálního rozvoje a mezinárodních studií Mendelovy univerzity v Brně se primárně věnuje výzkumu léčby drogové závislosti $\mathrm{v}$ interkulturní perspektivě a na základě poznatků $\mathrm{z}$ terénních šetření porovnává terapeutické programy v Peru, Nikaragui a České republice. Zaměřuje se přitom 
na problematiku spirituality v léčbě závislosti, retenci interních pacientů terapeutických komunit a jejich motivaci. Za tímto účelem $\mathrm{v}$ minulosti realizoval řadu projektů. Tradiční amazonská medicína, kterou v současnosti zkoumá $\mathrm{v}$ rámci české subkultury, je předmět jeho profesního zájmu od roku 2007.

Šárka Vosáhlová (1990, Nový Jičín) je absolventkou jednooborové psychologie na Filozofické fakultě Univerzity Palackého v Olomouci. Fenoménem ayahuascových obřadů se zabývala jak ve své postupové práci (Ayahuascové obřady v České republice), tak v práci diplomové (Ayahuascové obřady - motivace a efekty, 2015). V roce 2014 se rovněž aktivně zapojila do realizace výzkumného projektu UP
IGA: Výpravy za ayahuaskou: průzkum aktuálního jevu (hl. řesitel: PhDr. Veronika Kavenská, Ph.D.)

\section{Kontakty:}

Mgr. et Mgr. Miroslav Horák, Ph.D., Ústav jazykových a kulturních studií, Fakulta regionálního rozvoje a mezinárodních studií, Mendelova univerzita v Brně, Zemědělská 1/1665, 61300 Brno. Tel.: +420 545136 253, GSM: +420 727894 094, e-mail: miroslav.horak.ujks@ mendelu.cz, URL: http://jazyky.frrms.mendelu.cz/

Mgr. Šárka Vosáhlová, Petřvald 2 - Petřvaldík 18, 742 60, Petřvald. Tel.: +420 737653 877, e-mail: sarka.vosa@gmail.com 